Article

\title{
Understanding the Regioselective Hydrolysis of Human Serum Albumin by Zr(IV)-Substituted Polyoxotungstates Using Tryptophan Fluorescence Spectroscopy
}

\author{
Vincent Goovaerts, Karen Stroobants, Gregory Absillis and Tatjana N. Parac-Vogt* \\ Department of Chemistry, KU Leuven, Celestijnenlaan 200F, 3001 Heverlee, Belgium; \\ E-Mails: vincent.goovaerts@chem.kuleuven.be (V.G.); ks741@cam.ac.uk (K.S.); \\ Gregory.Absillis@chem.kuleuven.be (G.A.) \\ * Author to whom correspondence should be addressed; E-Mail: tatjana.vogt@chem.kuleuven.be; \\ Tel.: +32-16-327612; Fax: +32-16-327992.
}

Academic Editors: Greta Ricarda Patzke and Pierre-Emmanuel Car

Received: 11 February 2015 / Accepted: 15 May 2015 / Published: 29 May 2015

\begin{abstract}
The interaction between human serum albumin (HSA) and a series of $\mathrm{Zr}(\mathrm{IV})$-substituted polyoxometalates (POMs) (Lindqvist type POM $\left(\left({ }^{n} \mathrm{Bu} 4 \mathrm{~N}\right)_{6}\left[\left\{\mathrm{~W}_{5} \mathrm{O}{ }_{18} \mathrm{Zr}\right.\right.\right.$ $\left.\left.(\mu-\mathrm{OH})\}_{2}\right] \cdot 2 \mathrm{H}_{2} \mathrm{O}, \mathrm{Zr} 2-\mathrm{L} 2\right)$, two Keggin type POMs $\left(\left(\mathrm{Et}_{2} \mathrm{NH}_{2}\right)_{10}\left[\mathrm{Zr}\left(\mathrm{PW}_{11} \mathrm{O}_{39}\right)_{2}\right] \cdot 7 \mathrm{H}_{2} \mathrm{O}\right.$, $\mathrm{Zr} 1-\mathrm{K} 2$ and $\left.\left(\mathrm{Et}_{2} \mathrm{NH}_{2}\right)_{8}\left[\left\{\alpha-\mathrm{PW}_{11} \mathrm{O}_{39} \mathrm{Zr}(\mu-\mathrm{OH})\left(\mathrm{H}_{2} \mathrm{O}\right)\right\}_{2}\right] \cdot 7 \mathrm{H}_{2} \mathrm{O}, \quad \mathrm{Zr} 2-\mathrm{K} 2\right), \quad$ and two Wells-Dawson type POMs $\left(\mathrm{K}_{15} \mathrm{H}\left[\mathrm{Zr}\left(\alpha_{2}-\mathrm{P}_{2} \mathrm{~W}_{17} \mathrm{O}_{61}\right)_{2}\right] \cdot 25 \mathrm{H}_{2} \mathrm{O}, \quad \mathrm{Zr} 1-\mathrm{WD} 2\right.$ and $\left.\mathrm{Na}_{14}\left[\mathrm{Zr}_{4}\left(\mathrm{P}_{2} \mathrm{~W}_{16} \mathrm{O}_{59}\right)_{2}\left(\mu_{3}-\mathrm{O}\right)_{2}(\mathrm{OH})_{2}\left(\mathrm{H}_{2} \mathrm{O}\right)_{4}\right] \cdot 10 \mathrm{H}_{2} \mathrm{O}, \quad \mathrm{Zr} 4-\mathrm{WD} 2\right)$ was investigated by tryptophan (Trp) fluorescence spectroscopy. The fluorescence data were analyzed using the Tachiya model, ideally suited for multiple binding site analysis. The obtained quenching constants have the same order of magnitude for all the measured POM:protein complexes, ranging from $1.9 \times 10^{5} \mathrm{M}^{-1}$ to $5.1 \times 10^{5} \mathrm{M}^{-1}$. The number of bound POM molecules to HSA was in the range of 1.5 up to 3.5. The influence of the ionic strength was studied for the Zr1-WD2:HSA complex in the presence of $\mathrm{NaClO}_{4}$. The calculated quenching constant decreases upon increasing the ionic strength of the solution from $0.0004 \mathrm{M}$ to $0.5004 \mathrm{M}$, indicating the electrostatic nature of the interaction. The number of POM molecules bound to HSA increases from 1.0 to $4.8 .{ }^{31} \mathrm{P}$ NMR spectroscopy provided evidence for the stability of all investigated POM structures during the interaction with HSA.
\end{abstract}

Keywords: polyoxometalates; tryptophan fluorescence; artificial metalloproteases 


\section{Introduction}

Amino acids, the individual building blocks of proteins, are linked via peptide bonds, which have an extremely high stability towards hydrolysis. Under physiological reaction conditions, the half-life for the uncatalyzed hydrolysis of the peptide bond is estimated to be between 350 and 600 years [1]. Nevertheless, the selective hydrolysis of proteins into smaller, workable fragments is necessary in many biochemical and biomedical procedures [2]. For instance, protein hydrolysis is of prime importance for a broad range of proteomics techniques ranging from protein sequencing to protein identification [3-5]. Moreover, efficient and selective protein hydrolysis is also highly used in the food industry [6], leather processing [7], the cleaning industry [8] and medicine [9]. These applications demand the use of reagents that are on the one hand capable of hydrolyzing the extremely inert peptide bond, and achieving this reactivity in a highly selective manner on the other hand. Because most of the organic molecules are not sufficiently strong nucleophiles at physiological $\mathrm{pH}$, the hydrolytic activity of several metal salts and their corresponding complexes has been extensively investigated [2]. Although the improvements in this domain are considerable, most reported complexes need multistep reactions to be tethered to the protein, or can only be used in an extreme $\mathrm{pH}$ range, limiting their practical use as peptidases. Consequently, there is a need for new efficient peptidases.

Polyoxometalates (POMs) are a versatile and tunable class of negatively charged early transition metal-oxygen clusters [10-12]. These molecules are an assemblage of oxo-bridged early transition metals (mostly Mo, W, and V) in their highest oxidation state $[13,14]$. Their chemical and physical properties can be tuned, giving rise to a large number of possible applications in the fields of catalysis [15-17], material science [18-20] and medicine [21-24]. Moreover, the removal of one or more of the addenda atoms from the POM framework results in the formation of a lacunary species, which can coordinate different metal ions, resulting in the formation of metal-substituted POMs $[11,25]$. Metal-substituted POMs have been used as catalysts in several catalytic reactions, ranging from the epoxidation of olefins and alkanes to the splitting of water [26-29]. Additionally, POMs exhibit biological activity, which includes in vitro and in vivo anticancer, antiviral, antibiotic, antiprotozoal and antidiabetic activity [23,24,30]. Furthermore, inhibition of enzymes can be achieved as a result of the interaction of POMs with proteins [24,31], making POMs potential drugs for Alzheimer's disease [31]. Nonetheless, the exact molecular mechanism responsible for the medicinal activity of POMs has not yet been elucidated. Key components that influence the interaction between POMs and proteins include the size, shape and charge of the POM as well as the kind of incorporated metal ion [30,32-39].

It was previously reported by our research group that isopolyoxomolybdates [40-43], isopolyoxovandates $[44,45]$ and metal-substituted POMs [46] are able to efficiently hydrolyze the phopho(di)ester bonds in DNA and RNA model compounds. Moreover, hydrolysis of the highly inert peptide bond in dipeptides [46-50], oligopeptides [51], and several model proteins [34,52,53] by different types of POMs has been demonstrated. The hydrolysis of hen egg white lysozyme (HEWL) by the $\mathrm{Ce}(\mathrm{IV})$-substituted Keggin POM, $\left[\mathrm{Ce}\left(\mathrm{PW}_{11} \mathrm{O}_{39}\right)_{2}\right]^{10-}$, was the first reported example of protein hydrolysis promoted by a POM [34]. This study has shown that the negatively charged POM specifically interacts with positively charged patches on the protein surface, while at the same time it acts as a stabilizing ligand for the active metal ion, leading to regioselective hydrolysis. Interestingly, in preceding studies, it was found that the binding is not only directed by an electrostatic interaction between the 
negatively charged POM structure and positive patches on the surface of HEWL, but also by the coordination of the Ce(IV) ion to the carboxylate side chain of Glu or Asp amino acids [34].

Later we demonstrated that due to the high Lewis acidity of the zirconium(IV) ion, the $\mathrm{Zr}(\mathrm{IV})$-substituted polytungstates were efficient catalysts for the hydrolysis of the peptide bond [49-51,54]. The hydrolytic activity of a series of $\mathrm{Zr}(\mathrm{IV}$ )-substituted POMs toward human serum albumin (HSA) has been investigated in detail recently [52]. In this study, it was found that HSA was selectively hydrolyzed by $\mathrm{Zr}(\mathrm{IV})$-substituted Lindqvist $\left(\left({ }^{\mathrm{B}} \mathrm{Bu} 4 \mathrm{~N}_{6}\left[\left\{\mathrm{~W}_{5} \mathrm{O}_{18} \mathrm{Zr}(\mu-\mathrm{OH})\right\}_{2}\right] \cdot 2 \mathrm{H}_{2} \mathrm{O}, \mathrm{Zr} 2-\mathrm{L} 2\right)\right.$, Keggin $\left(\left(\mathrm{Et}_{2} \mathrm{NH}_{2}\right)_{10}\left[\mathrm{Zr}\left(\mathrm{PW}_{11} \mathrm{O}_{39}\right)_{2}\right] \cdot 7 \mathrm{H}_{2} \mathrm{O}, \quad \mathrm{Zr} 1-\mathrm{K} 2, \quad\right.$ and $\quad\left(\mathrm{Et}_{2} \mathrm{NH}_{2}\right)_{8}\left[\left\{\alpha-\mathrm{PW}{ }_{11} \mathrm{O}_{39} \mathrm{Zr}(\mu-\mathrm{OH})\left(\mathrm{H}_{2} \mathrm{O}\right)\right\}_{2}\right] \cdot 7 \mathrm{H}_{2} \mathrm{O}$, $\mathrm{Zr} 2-\mathrm{K} 2)$, and Wells-Dawson $\left(\mathrm{K}_{15} \mathrm{H}\left[\mathrm{Zr}\left(\alpha_{2}-\mathrm{P}_{2} \mathrm{~W}_{17} \mathrm{O}_{61}\right)_{2}\right] \cdot 25 \mathrm{H}_{2} \mathrm{O}, \mathrm{Zr} 1-\mathrm{WD} 2\right.$, and $\mathrm{Na}_{14}\left[\mathrm{Zr}_{4}\left(\mathrm{P}_{2} \mathrm{~W}_{16} \mathrm{O}_{59}\right)_{2}\right.$ $\left.\left.\left(\mu_{3}-\mathrm{O}\right)_{2}(\mathrm{OH})_{2}\left(\mathrm{H}_{2} \mathrm{O}\right)_{4}\right] \cdot 10 \mathrm{H}_{2} \mathrm{O}, \mathrm{Zr} 4-\mathrm{WD} 2\right)$ type POMs. Although all POMs exhibited a similar hydrolysis pattern, the Wells-Dawson type POMs showed the highest reactivity among the investigated complexes towards the hydrolysis of HSA. Albumin proteins are frequently studied proteins in interaction studies because of their known primary sequence and the stability of their tertiary structure in solution [33,36-39,55]. HSA contains one tryptophan residue which is located at position 214 , and the use of fluorescence quenching studies are an excellent tool to quantify the strength of the interaction and the number of binding sites for molecules that interact with HSA [56]. A detailed understanding of the parameters responsible for the interaction on a molecular level is necessary to tune the selectivity and rationally design metal-substituted POMs with explicit interaction properties. In addition, the establishment of the correlation between the rate of protein hydrolysis by metal-substituted POMs and the strength of their interaction that precedes the hydrolysis will result in a faster achievement of the application of metal-substituted POMs as artificial peptidases.

In this study, a series of $\mathrm{Zr}(\mathrm{IV})$-substituted POMs, which were previously proven to be hydrolytically active towards HSA, were investigated with tryptophan (Trp) fluorescence spectroscopy in order to gain insight into the interaction between the POMs and HSA, which precedes the actual protein hydrolysis. The quenching of Trp214 fluorescence by Zr1-K2, Zr2-K2, Zr2-L2, Zr1-WD2, and Zr4-WD2 was investigated at physiological $\mathrm{pH}(\mathrm{pH}$ 7.4) and room temperature to quantify the strength of the binding and identify the stoichiometry of this interaction.

\section{Results and Discussion}

\subsection{Tryptophan Fluorescence Spectroscopy}

Fluorescence quenching was used to study the interaction of a set of $\mathrm{Zr}(\mathrm{IV})$-substituted POMs with HSA. The series consist of one Lindqvist type POM $\left(\left({ }^{n} \mathrm{Bu} 4 \mathrm{~N}\right)_{6}\left[\left\{\mathrm{~W}_{5} \mathrm{O}_{18} \mathrm{Zr}(\mu-\mathrm{OH})\right\}_{2}\right] \cdot 2 \mathrm{H}_{2} \mathrm{O}, \mathrm{Zr} 2-\mathrm{L} 2\right)$, two Keggin type POMs $\left(\left(\mathrm{Et}_{2} \mathrm{NH}_{2}\right)_{10}\left[\mathrm{Zr}\left(\mathrm{PW}_{11} \mathrm{O}_{39}\right)_{2}\right] \cdot 7 \mathrm{H}_{2} \mathrm{O}, \mathrm{Zr} 1-\mathrm{K} 2\right.$ and $\left(\mathrm{Et}_{2} \mathrm{NH}_{2}\right)_{8}\left[\left\{\alpha-\mathrm{PW}{ }_{11} \mathrm{O}_{39} \mathrm{Zr}\right.\right.$ $\left.\left.\left.(\mu-\mathrm{OH})\left(\mathrm{H}_{2} \mathrm{O}\right)\right\}_{2}\right] \cdot 7 \mathrm{H}_{2} \mathrm{O}, \mathrm{Zr} 2-\mathrm{K} 2\right)$, and two Wells-Dawson type POMs $\left(\mathrm{K}_{15} \mathrm{H}\left[\mathrm{Zr}\left(\alpha_{2}-\mathrm{P}_{2} \mathrm{~W}_{17} \mathrm{O}_{61}\right)_{2}\right] \cdot 25 \mathrm{H}_{2} \mathrm{O}\right.$, $\mathrm{Zr} 1-\mathrm{WD} 2$ and $\left.\mathrm{Na}_{14}\left[\mathrm{Zr}_{4}\left(\mathrm{P}_{2} \mathrm{~W}_{16} \mathrm{O}_{59}\right)_{2}\left(\mu_{3}-\mathrm{O}\right)_{2}(\mathrm{OH})_{2}\left(\mathrm{H}_{2} \mathrm{O}\right)_{4}\right] \cdot 10 \mathrm{H}_{2} \mathrm{O}, \mathrm{Zr} 4-\mathrm{WD} 2\right)$, as depicted in Figure 1. 


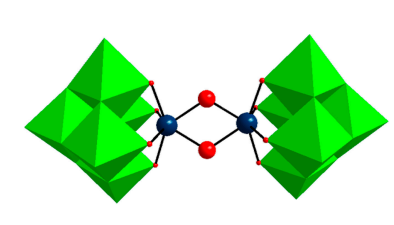

Zr2-L2

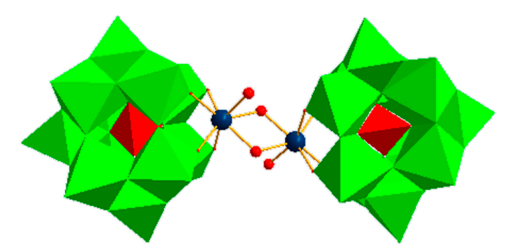

$\mathrm{Zr} 2-\mathrm{K} 2$

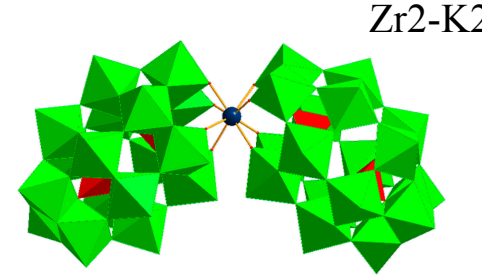

Zr1-WD2

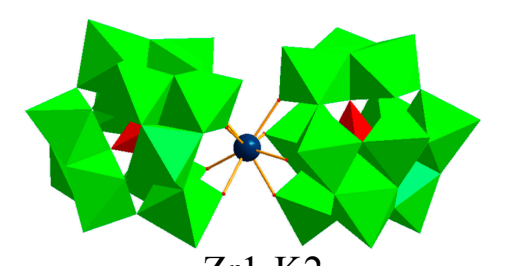

Zr1-K2

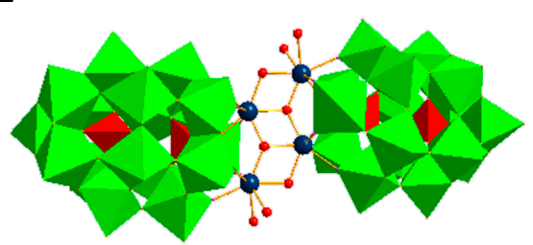

Zr4-WD2

Figure 1. Combined polyhedral/ball-and-stick representations of Zr2-L2, Zr1-K2, Zr2-K2, Zr1-WD2, and Zr4-WD2. (Green octahedra: WO6, red tetrahedra: PO4, teal blue: $\mathrm{Zr}(\mathrm{IV})$ ion, red balls: oxygen atoms).

HSA is a $66.5 \mathrm{kDa}$ protein and consists of 585 amino acid residues including 1 tryptophan (Trp) residue, 19 tyrosine (Tyr) residues and 17 disulfide bonds. Emission of HSA is dominated by the Trp residue, which absorbs at the longest wavelength and displays the largest extinction co-efficient. Moreover, energy absorbed by phenylalanine (Phe) and Tyr residues is often efficiently transferred to the Trp residues in the same protein [57]. In these steady state fluorescence experiments, the concentration of HSA was kept constant at $10 \mu \mathrm{M}$, while the concentration of the respective POMs was increased stepwise from 0 to $10 \mu \mathrm{M}$ with increments of $1 \mu \mathrm{M}$. The quenching of the Trp fluorescence by Zr2-L2 is shown in Figure 2, and similar behavior was observed for the other POMs (Figures S1-S4). The Tachiya model, presented in Equation (1), was used for analysis of the strength and stoichiometry of the binding [56]:

$$
\log \left(\frac{F_{0}-F}{F}\right)=m \times \log \left(K_{a}\right)+m \times \log \left([Q]-[M] \frac{F_{0}-F}{F}\right)
$$

where $F_{0}$ is the unquenched fluorescence intensity, $F$ the fluorescence in the presence of the quencher, $[Q]$ the concentration of the quencher, $[M]$ the concentration of protein and $\mathrm{m}$ the number of binding sites. This model is used since a stoichiometry higher than 1 is expected [52]. The key advantage of using this equation is that it offers the option to extract the quenching constant or association constant $\left(K_{\mathrm{a}}\right)$ as well as the number of bound molecules $(m)$ directly. The plots of the equations for the different POM:HSA complexes can be seen in the insets of the respective figures. The calculated values of the quenching constants, their corresponding number of bound molecules, the HSA hydrolysis rate (\%) [52], and the net charge of the POMs are given in Table 1. 


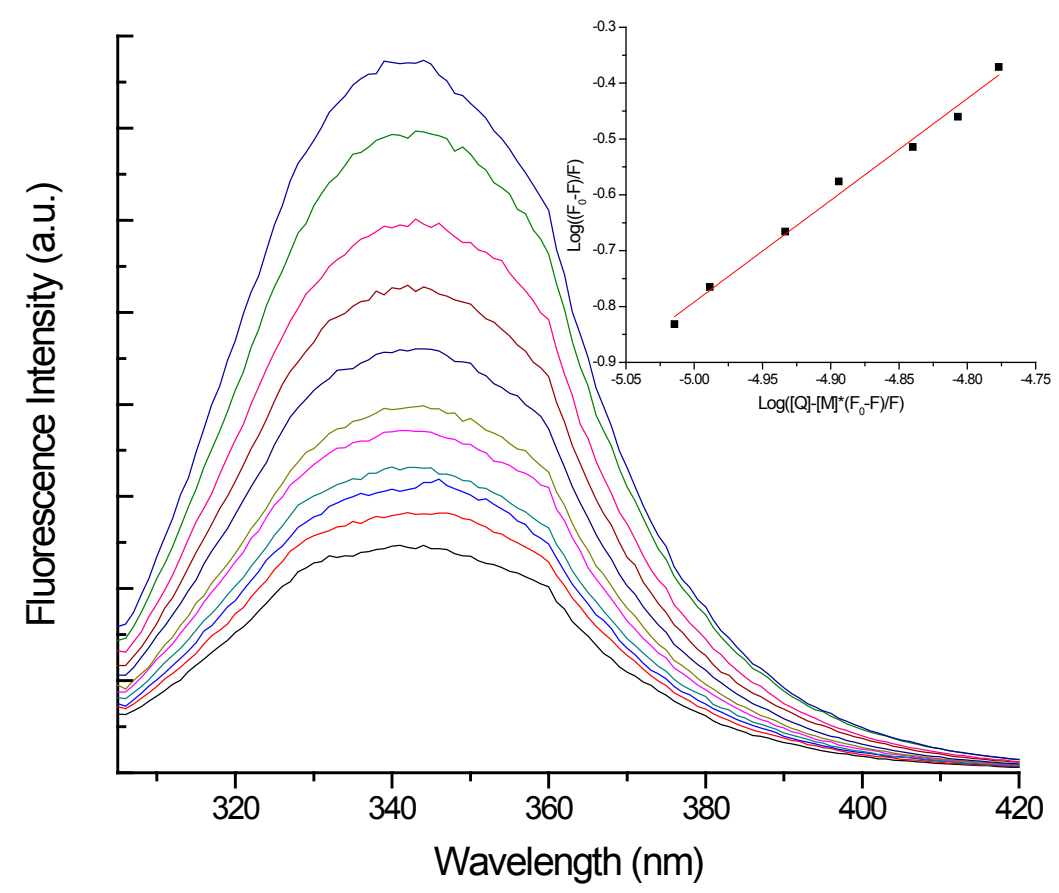

Figure 2. Emission fluorescence spectra of HSA in the absence and presence of different concentrations of $\mathrm{Zr} 2-\mathrm{L} 2\left([\mathrm{HSA}]=10^{-5} \mathrm{M}, \mathrm{pH}=7.4\right)$. From top to bottom, the concentration of Zr2-L2 increased stepwise from 0 to $10^{-5} \mathrm{M}$ with increments of $10^{-6} \mathrm{M}$. In the inset, the plot of the Tachiya equation is given (with $R^{2}=0.99$ ). From the plot, $K_{\mathrm{a}}$ and $m$ were calculated to be $2.0 \times 10^{5} \mathrm{M}^{-1}$ and 3.02 , respectively.

Table 1. Calculated values of the quenching constants, their corresponding number of bound molecules, the percentage of hydrolyzed human serum albumin (has) after $48 \mathrm{~h}$ incubation at $\mathrm{pH} 7.4$ and $60{ }^{\circ} \mathrm{C}$ [52] and their polyoxometalates (POM) net charge for different POM:HSA complexes.

\begin{tabular}{ccccc}
\hline POM & $\boldsymbol{K}_{\mathbf{a}}\left(\mathbf{M}^{-\mathbf{1}}\right)$ & $\boldsymbol{m}$ & Hydrolysis $(\%)$ after 48 $\mathbf{h}[\mathbf{5 2}]$ & POM Net Charge \\
\hline Zr1-K2 & $1.9 \times 10^{5}$ & 3.44 & $<35$ & -10 \\
Zr2-K2 & $2.5 \times 10^{5}$ & 2.23 & $<35$ & -6 \\
Zr2-L2 & $2.0 \times 10^{5}$ & 3.02 & $<35$ & -4 \\
Zr1-WD2 & $5.1 \times 10^{5}$ & 1.52 & $\sim 75$ & -16 \\
Zr4-WD2 & $2.8 \times 10^{5}$ & 2.05 & $\sim 50$ & -4 \\
\hline
\end{tabular}

From Table 1, it can be seen that the number of bound $\mathrm{Zr}(\mathrm{IV})$-substituted POM complexes per HSA molecule varies between 1.52 and 3.44. This indication for the simultaneous binding of multiple POM molecules to HSA is not surprising since we have previously shown that up to four cleavage positions were observed for all five POM complexes [52]. Since HSA is a large protein, it is reasonable to assume that it can interact with more than one POM at the same time. In addition, the two largest POMs (Zr4-WD2 and Zr1-WD2) show the lowest value for the number of molecules bound to HSA, while a higher stoichiometry is obtained for the smaller POMs. This is reflected in the change of a 2:1 POM:HSA complex observed for (Zr4-WD2 and Zr1-WD2) to a 3:1 (for Zr2-L2) and nearly a 4:1 POM:HSA complex for Zr1-K2. 
As is also shown in Table 1, the strength of the binding to HSA is in the same order of magnitude $\left(10^{5} \mathrm{M}^{-1}\right)$ for all studied $\mathrm{Zr}(\mathrm{IV})$-substituted POMs. The quenching of the fluorescence of HSA has been extensively studied with different types of POMs, including Keggin, Wells-Dawson, Lindqvist and wheel-shaped structured POMs [33,36,37,39]. The calculated values for the quenching constants of the $\mathrm{Zr}(\mathrm{IV})$-substituted POMs are comparable to the reported values obtained for the lacunary Keggin $\left(\mathrm{K}_{7} \mathrm{PW}_{11} \mathrm{O}_{39}, 2.9 \times 10^{5} \mathrm{M}^{-1}\right)[58]$, and the Ni(II)-substituted Wells-Dawson POM $\left(\alpha_{2}-\left[\mathrm{NiP}_{2} \mathrm{~W}_{17} \mathrm{O}_{61}\right]^{8-}\right.$, $1.15 \times 10^{5} \mathrm{M}^{-1}$ ) [37]. However, the values of the quenching constants for the $\mathrm{Zr}(\mathrm{IV})$-substituted POMs are one order of magnitude larger than the corresponding values for the $\mathrm{Eu}(\mathrm{III})$-substituted analogues of the Keggin $\left(\mathrm{K}_{4} \mathrm{EuPW}_{11} \mathrm{O}_{39}, 6.1 \times 10^{4} \mathrm{M}^{-1}\right)$ [58], and Lindqvist $\left(\mathrm{Na} 9\left[\mathrm{Eu}\left(\mathrm{W}_{10} \mathrm{O}_{36}\right)\right], 4.8 \times 10^{4} \mathrm{M}^{-1}\right)$ [39] type POMs. In part, this might be a result of the larger POM net charge of the $\mathrm{Zr}(\mathrm{IV})$-substituted POMs as compared to the $\mathrm{Eu}(\mathrm{III})$ analogues. Furthermore, the $\mathrm{Zr}(\mathrm{IV})$-substituted POMs are larger than their $\mathrm{Eu}(\mathrm{III})$ counterparts, resulting in a larger negatively charged surface that is able to interact stronger with the positive patches on the HSA surface. For instance, the larger charge of the $\mathrm{Zr}(\mathrm{IV})$-substituted Keggin type POMs evolves from the slight difference in structure; they all have two POM ligands, while the $\mathrm{Eu}(\mathrm{III})$ analogue only has one. The larger negative charge results in a stronger interaction and hence, a larger value for the quenching constant, since the POM:protein interactions are mainly electrostatic in nature [39].

A final important observation which is made from the data in Table 1 is that the reactivity of the studied POMs is correlated to the strength of their interaction with the HSA protein. Zr1-WD2 not only possesses the largest value of $K_{\mathrm{a}}$, but also displayed the fastest rate of HSA hydrolysis $(\sim 75 \%$ after $48 \mathrm{~h}$ incubation) in our previous reaction study. The second strongest binding POM, Zr4-WD2, exhibited the second fastest hydrolysis of HSA ( $\sim 50 \%$ after $48 \mathrm{~h}$ incubation). Conclusions for the other three POMs cannot be made, since it was not possible to distinguish between them in the hydrolysis experiments. However, the relationship between the reactivity and interaction strength can be expected to be valid for the other $\mathrm{Zr}(\mathrm{IV})$-substituted POMs as well. In addition, it can be deduced that small changes in the interaction strength induce large changes in the hydrolysis reactivity toward the stable peptide bonds in HSA.

Although the net charge of the POM clearly plays an important role, it is not the only factor influencing the interaction with HSA. This can for example be seen for the value of the quenching constant for the Zr1-K2:HSA complex; this complex has a very similar value of $K_{\mathrm{a}}$ as compared to Zr2-L2, while the net charges of the POMs are -10 and -4 , respectively. Consequently, it is proposed that the size and shape of the POM considerably affect the interaction as well. Moreover, different cations can cause changes in the protein aggregation and alter interaction processes. In addition, the substituted metal ion or the amount of substituted metal ions can play an important role in the interaction behavior. This is a result of the hydrolysis pattern of the $\operatorname{Zr}(\mathrm{IV})$-substituted POMs. One cleavage site (Arg114-Leu115) is located in the central cleft of HSA. This cleft has a positive inner surface [59]. The three other cleavage sites (Ala257-Asp258, Lys313-Asp314, and Cys392-Glu393) are located near a positive surface patch with a negatively charged amino acid in the upstream position (Asp or Glu) [52], suggesting that the positively charged $\mathrm{Zr}(\mathrm{IV})$ ion is involved in the electronic interaction process as well.

To further investigate the electrostatic nature of the interactions between POMs and proteins, the Trp fluorescence quenching of HSA by Zr1-WD2 was studied at different ionic strength conditions. 
Since electrostatic interactions are known to diminish when the ionic strength (I) is increased, the effect of $\mathrm{NaClO}_{4}$ addition on the interaction parameters was studied. The ionic strength can be calculated using Equation (2):

$$
I=\frac{1}{2} \sum_{i=1}^{n} C_{i} Z_{i}^{2}
$$

where $\mathrm{C}_{\mathrm{i}}$ is the molar concentration of the ion in $\mathrm{M}$ and $\mathrm{Z}_{\mathrm{i}}$ is the charge of that ion. The ionic strength was varied in the range of $0.0004 \mathrm{M}$ to $0.5004 \mathrm{M}$. The Trp fluorescence quenching of HSA was performed for five ionic strength values in this range and in the presence of the Zr1-WD2 POM, as this POM displayed the strongest interaction in the previous experiments. The analysis of the data was done using the Tachiya model [56] and the resulting parameters are shown in Table 2.

Table 2. Calculated values of the quenching constants and their corresponding number of bound molecules for the 1:2 Zr(IV)-substituted Wells-Dawson POM:HSA complex at different ionic strength conditions.

\begin{tabular}{ccc}
\hline Ionic Strength $(\mathbf{M})$ & $\boldsymbol{K}_{\mathrm{a}}\left(\mathbf{M}^{-\mathbf{1}}\right)$ & $\boldsymbol{m}$ \\
\hline 0.0004 & $5.1 \times 10^{5}$ & 1.52 \\
0.0014 & $4.4 \times 10^{5}$ & 0.95 \\
0.0504 & $2.4 \times 10^{5}$ & 2.44 \\
0.1004 & $2.3 \times 10^{5}$ & 2.65 \\
0.2504 & $1.9 \times 10^{5}$ & 2.95 \\
0.5004 & $1.5 \times 10^{5}$ & 4.81 \\
\hline
\end{tabular}

From Table 2, it can be concluded that the quenching constant decreases upon increasing the ionic strength of the solution. This observation can be explained by the thermodynamic parameters of the electrostatic interaction. The entropy becomes more unfavorable when the ionic strength increases [60], resulting in a weaker interaction. This is the result of the shielding of the high negative charge $(-16)$ of $\mathrm{Zr1-WD} 2$ by the salt ions. Moreover, this lower quenching constant indicates that each binding is weaker because of the simultaneous disruption of the interaction with the positively charged residues of HSA. Although the interaction strength reduces with a factor larger than three, it remains in the same order of magnitude $\left(10^{5} \mathrm{M}^{-1}\right)$ regardless of the change in ionic strength. The effect of the ionic strength is not as pronounced as it was the case for a Keggin shaped POM $\left(\left[\mathrm{H}_{2} \mathrm{~W}_{12} \mathrm{O}_{40}\right]^{6-}\right)$ where a decrease in binding constant was observed of more than two orders of magnitude [61]. Therefore, it can be concluded that the interaction between Zr1-WD2 and HSA persists even in solutions with high ionic strengths.

A final important observation which is made from the data in Table 2 is that the number of bound molecules increases upon increasing the ionic strength. This result can be understood by considering the electrostatic nature of the POM:protein interaction. While the high negative charge of Zr1-WD2 results in the strongest interaction with HSA, it also leads to a lower number of possible binding positions as compared to the other POMs. This presumably is the result of repulsive forces with negatively charged residues on the HSA surface in close proximity to the positively charged regions to which the POMs tend to bind. When $\mathrm{NaClO}_{4}$ is added, the high negative charge of $\mathrm{Zr} 1-\mathrm{WD} 2$ will partly be shielded, resulting in more possible binding positions. In previous studies performed in our research group, by 
using isothermal titration calorimetry, it was found that four Zr1-WD2 POMs were able to bind to HSA [53]. Therefore, it is expected that the number of bound molecules will plateau upon further increasing the ionic strength. As for the other $\mathrm{Zr}(\mathrm{IV})$-substituted POMs, it is reasonable to assume the POMs will display similar behavior upon increasing the ionic strength; the strength of the binding will decrease as a result of the shielding of the charges by $\mathrm{NaClO}_{4}$, while the number of bound molecules will increase for the same reason. The smaller Keggin and Lindqvist type POMs will probably be able to bind more POM molecules per HSA, as was seen in the fluorescence quenching experiments without added salt. The value of bound molecules could go up as high as eleven, as was reported for a Keggin shaped POM $\left(\left[\mathrm{H}_{2} \mathrm{~W}_{12} \mathrm{O}_{40}\right]^{6-}\right)[61]$.

\subsection{Polyoxometalate Stability in the Presence of HSA}

${ }^{31} \mathrm{P}$ NMR spectra of the Zr1-K2, Zr2-K2, Zr1-WD2 and Zr4-WD2 POMs in phosphate buffer $\left(10 \mathrm{mM}, \mathrm{pD} 7.4,10 \% \mathrm{D}_{2} \mathrm{O}\right)$ were measured in the absence and presence of 0.1 equivalents of HSA. The Zr2-L2 POM could not be investigated in these experiments since this POM does not contain any phosphorus atoms. The Keggin structures are composed of one or two $\mathrm{Zr}(\mathrm{IV})$ metal ions, respectively, surrounded by two lacunary Keggin units with a $\mathrm{PO}_{4}$ tetrahedron at the centre (Figure 1). The environment of the phosphorus atoms is symmetrical resulting in a single resonance for the phosphorus atoms. However, due to the formation of two isomers of the $\mathrm{Zr} 1-\mathrm{K} 2$ compound, two adjacent resonances were reported to characterize this POM [62]. The Wells-Dawson compounds contain a second $\mathrm{PO}_{4}$ tetrahedron near the POM unit centre (Figure 1), they also are symmetrical and are characterized by two ${ }^{31} \mathrm{P}$ NMR signals. The resonance for the phosphorus atom close to the $\mathrm{Zr}(\mathrm{IV})$ metal falls within the ppm range where the characteristic peaks for metal-substituted Keggins are found due to the similar electrostatic environment. The second resonance for the phosphorus atom further away from the incorporated metal ion(s) is shifted downfield. As shown in Figure 3, there is no shift in the peak positions of the characteristic Zr1-WD2 resonances (at -9.33 and $-13.94 \mathrm{ppm}$ ) in the presence of HSA, indicating the stability of the POM upon interaction with the protein. It should not be surprising that these polyoxotungstates are stable as this was already previously demonstrated by various techniques [63-65]. In addition, the slight decrease in the intensity of the POM peaks can be correlated with the formation of a large molecular complex with HSA which has a longer correlation time and thus a faster relaxation. The shifting of ${ }^{31} \mathrm{P}$ NMR resonances was also not observed for the Zr4-WD2 (resonances at -7.04 and $-14.26 \mathrm{ppm}$ ), Zr1-K2 (resonances at -14.60 and $-14.69 \mathrm{ppm}$ ) and Zr2-K2 (resonance at $-13.60 \mathrm{ppm}$ ) POMs upon addition of 0.1 equivalents of HSA. Similarly to Zr1-WD2, an intensity decrease was observed for all POM resonances upon increasing the HSA concentration, giving an additional indication for the POM:HSA interactions. The absence of any new peaks in the ${ }^{31} \mathrm{P}$ NMR provides evidence for the stability of all investigated POM structures during the interaction with the albumin protein, indicating a fast exchange binding mechanism between the POM structures and HSA [66].

Previous experiments in our research group on the mechanism of the hydrolysis of the peptide bond in di- and oligopeptides have demonstrated the need for the accessibility of the hydrolytically active metal ion. It was shown that the coordination of the peptide to $\mathrm{Zr}(\mathrm{IV})$ results in the polarization of the peptide carbonyl group, which speeds up the hydrolysis [49-51,54]. As a result of the saturated coordination sphere of $\mathrm{Zr}(\mathrm{IV})$ in the 1:2 POM structures, it is expected that these POMs display the 
slowest hydrolysis rate. However, equilibrium exists between the monomeric and dimeric species of Zr1-WD2, Zr1-K2, Zr2-K2 and Zr2-L2, depending on the $\mathrm{pH}$ and concentration of the solution where lower concentrations favored the formation of the monomeric species [49-51,67,68]. Moreover, the addition of protein can also shift the equilibrium towards the monomeric species [51]. These species have four free coordination sites around $\mathrm{Zr}(\mathrm{IV})$, resulting in faster hydrolysis as was demonstrated for Zr1-WD2 [52]. For this reason, the hydrolysis of the peptide bond in HSA is by a similar mechanism as for short peptides [51], although the interaction pattern was demonstrated to be very different. In HSA, it was shown that the POM structures are able to interact with positive surface patches with a supplementary interaction of $\mathrm{Zr}(\mathrm{IV})$ with an upstream negatively charged amino acid (Asp or Glu) and thereby influencing the selectivity [52].
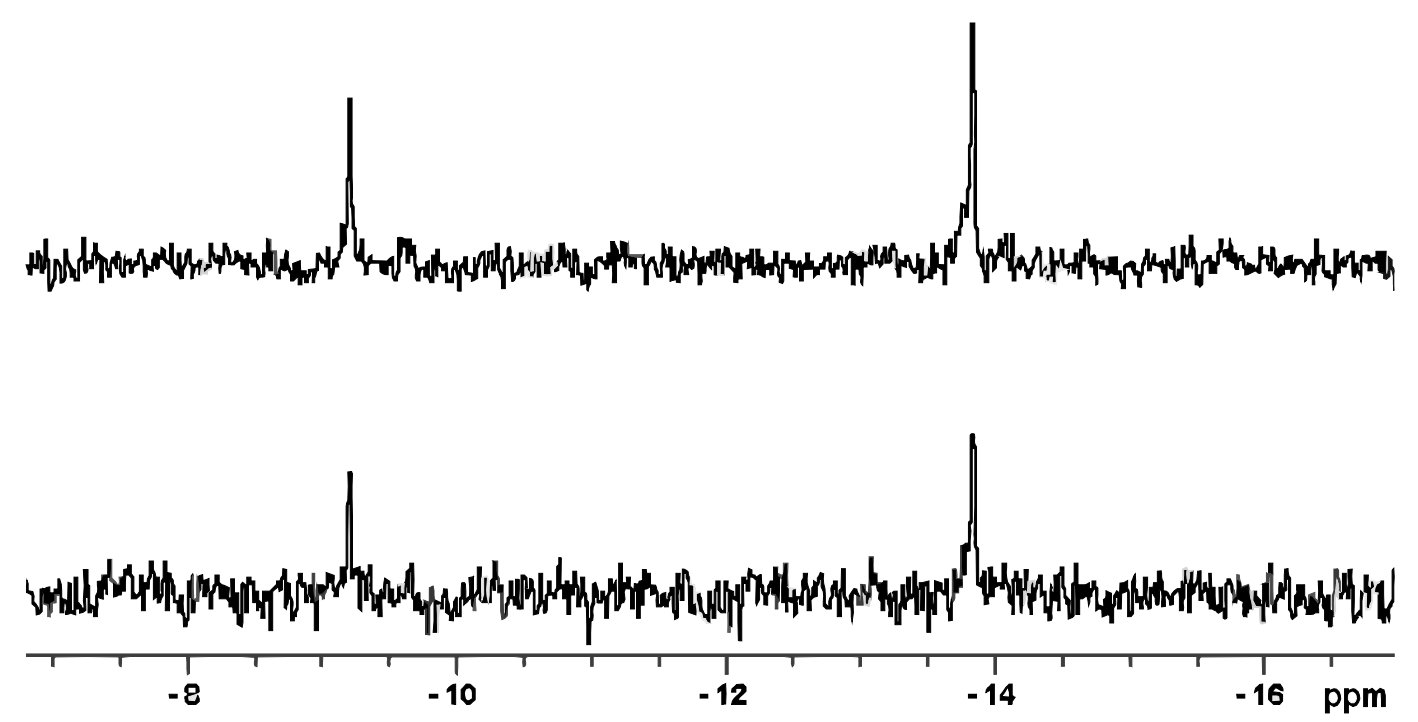

Figure 3. ${ }^{31} \mathrm{P}$ NMR spectra of Zr1-WD2 $(2.0 \mathrm{mM})$ in the absence (top) and presence (bottom) of HSA $(0.2 \mathrm{mM})$ in phosphate buffer $\left(10 \mathrm{mM}, \mathrm{pH} 7.4,10 \% \mathrm{D}_{2} \mathrm{O}\right)$. The peak positions at -9.33 and -13.94 ppm do not change upon addition of HSA.

\section{Experimental Section}

\subsection{Materials}

Human serum albumin (HSA) was purchased from Sigma-Aldrich (Schnelldorf, Germany) in the highest available purity and was used without further purification. ( $\left.\mathrm{Et}_{2} \mathrm{NH}_{2}\right)_{10}\left[\mathrm{Zr}\left(\mathrm{PW}_{11} \mathrm{O}_{39}\right)_{2}\right] \cdot 7 \mathrm{H}_{2} \mathrm{O}$ $(\mathrm{Zr} 1-\mathrm{K} 2)[62],\left(\mathrm{Et}_{2} \mathrm{NH}_{2}\right)_{8}\left[\left\{\alpha-\mathrm{PW}{ }_{11} \mathrm{O}_{39} \mathrm{Zr}(\mu-\mathrm{OH})\left(\mathrm{H}_{2} \mathrm{O}\right)\right\}_{2}\right] \cdot 7 \mathrm{H}_{2} \mathrm{O}(\mathrm{Zr} 2-\mathrm{K} 2)[69],\left({ }^{\mathrm{n}} \mathrm{Bu} 4 \mathrm{~N}\right)_{6}\left[\left\{\mathrm{~W}_{5} \mathrm{O} 18 \mathrm{Zr}(\mu-\right.\right.$ $\left.\mathrm{OH})\}_{2}\right] \cdot 2 \mathrm{H}_{2} \mathrm{O} \quad(\mathrm{Zr} 2-\mathrm{L} 2) \quad[70], \quad \mathrm{K}_{15} \mathrm{H}\left[\mathrm{Zr}\left(\alpha_{2}-\mathrm{P}_{2} \mathrm{~W}_{17} \mathrm{O}_{61}\right)_{2}\right] \cdot 25 \mathrm{H}_{2} \mathrm{O} \quad(\mathrm{Zr} 1-\mathrm{WD} 2) \quad$ [62] or $\mathrm{Na}_{14}\left[\mathrm{Zr}_{4}\left(\mathrm{P}_{2} \mathrm{~W}_{16} \mathrm{O}{ }_{59}\right)_{2}\left(\mu_{3}-\mathrm{O}\right)_{2}(\mathrm{OH})_{2}\left(\mathrm{H}_{2} \mathrm{O}\right)_{4}\right] \cdot 10 \mathrm{H}_{2} \mathrm{O} \quad(\mathrm{Zr} 4-\mathrm{WD} 2) \quad[71]$ were prepared by the published procedures.

\subsection{Fluorescence Spectroscopy Studies}

Steady state fluorescence experiments were recorded on a Photon Technology Quanta Master (North Edison, NJ, USA) QM-6/2005 spectrofluorimeter. Quartz cuvettes with $10.0 \mathrm{~mm}$ optical path length were used. Spectra were recorded in a buffered $10 \mu \mathrm{M}$ protein concentration solution (phosphate buffer, 
$\mathrm{pH}=7.4$ ) at room temperature monitoring the emission from $305 \mathrm{~nm}$ to $420 \mathrm{~nm}$, with a maximum at approximately $340 \mathrm{~nm}$. Although several organic cations are used as counter ions for the polyoxoanions, no precipitation is observed as a result of the used phosphate buffer. To examine the influence of the ionic strength, $\mathrm{NaClO}_{4}$ was added with concentrations in the range of 0.001 to $0.5 \mathrm{M}$. Excitation of the samples took place at $295 \mathrm{~nm}$ to avoid excitation of tyrosine residues. The emission and excitation slit widths were opened at $0.37 \mathrm{~mm}$ (resolution of $1.0 \mathrm{~nm}$ ). The POM concentration was increased stepwise from 0 to $10 \mu \mathrm{M}$ with increments of $1.0 \mu \mathrm{M}$. The fluorescence data of the POMs were analyzed using the Tachiya model, Equation (1) [56].

\section{3. ${ }^{31} P$ NMR Spectroscopy}

Solutions $(0.5 \mathrm{~mL})$ containing 0.1 or $0.2 \mathrm{mM}$ of HSA and 1.0 or $2.0 \mathrm{mM}$ of POM were prepared in phosphate buffer $\left(10.0 \mathrm{mM}-\mathrm{pH} 7.4-10 \% \mathrm{D}_{2} \mathrm{O}\right) .{ }^{31} \mathrm{P}$ NMR spectra were recorded directly after mixing on a Bruker (Karlsruhe, Germany) Avance 400 (161.98 MHz) spectrometer. As an external standard, $25 \% \mathrm{H}_{3} \mathrm{PO}_{4}$ in $\mathrm{D}_{2} \mathrm{O}$ in a sealed capillary was used.

\section{Conclusions}

The knowledge of the interaction between hydrolytically active POMs and proteins on a molecular level is necessary to further optimize the hydrolytic selectivity of metal-substituted POMs as artificial proteases. In this study, a direct correlation between the rate of protein hydrolysis by metal-substituted POMs and the strength of their interaction, preceding this reaction, was established for the first time.

Fluorescence spectroscopy was used to study the interaction between a series of $\mathrm{Zr}(\mathrm{IV})$-substituted POMs and HSA. Analysis of the fluorescence quenching of HSA in the presence of these POMs has resulted in a binding stoichiometry ranging from 2:1 POM:HSA for the larger POMs up to 3:1 and even 4:1 for the smaller POMs and binding constants in the order of $10^{5} \mathrm{M}^{-1}$. It was shown that the Wells-Dawson POM, Zr1-WD2, displays the strongest interaction with HSA, which correlates to its high hydrolysis reactivity, as was previously reported. This correlation between the hydrolysis reactivity and interaction strength was not established before and seems to be valid for the other $\mathrm{Zr}(\mathrm{IV})$-substituted POMs as well.

The influence of the ionic strength was studied for the $\mathrm{Zr1-WD2:HSA}$ complex by adding $\mathrm{NaClO}_{4}$. It was found that the value of the quenching constants decreases upon increasing the ionic strength of the solution from $0.0004 \mathrm{M}$ to $0.5004 \mathrm{M}$. Nevertheless, it was found that the number of bound molecules increased from 0.95 to 4.81 . While the increased number of bound molecules is the result of the shielding of the high negative charge of Zr1-WD2, resulting in more possible binding positions, the lower quenching constant indicates that each binding is weaker due to the simultaneous disruption of the interactions with positively charged residues. ${ }^{31} \mathrm{P}$ NMR spectroscopy was used to investigate the stability of all phosphorus containing POMs upon interaction with HSA. The lack of new peaks in the ${ }^{31} \mathrm{P}$ NMR spectra of all investigated POMs provides evidence for the stability during their interaction with HSA.

The presented interaction study complements the ongoing research in our group which mainly focuses on the hydrolysis of proteins by POMs, and greatly contributes to the establishment of a structure-activity relationship of metal-substituted polyoxotungstates as a new class of metalloproteases. 


\section{Acknowledgments}

T.N.P.V. thanks KU Leuven and F.W.O. Flanders for the financial support. V.G. acknowledges KU Leuven (Belgium) for a doctoral fellowship. K.S. thanks F.W.O. Flanders for the doctoral fellowship and G.A. acknowledges F.W.O. Flanders for the post-doctoral fellowship.

\section{Author Contributions}

V.G.: Literature research, tryptophan fluorescence quenching experiments, analysis and discussion of the results; K.S. and G.A.: Synthesis of polyoxometalates and ${ }^{31} \mathrm{P}$ NMR spectroscopy experiments; T.N.P.-V.: careful follow-up and improvement of the manuscript.

\section{Conflicts of Interest}

The authors declare no conflict of interest.

\section{References}

1. Radzicka, A.; Wolfenden, R. Rates of uncatalyzed peptide bond hydrolysis in neutral solution and the transition state affinities of proteases. J. Am. Chem. Soc. 1996, 118, 6105-6109.

2. Grant, K.B.; Kassai, M. Major advances in the hydrolysis of peptides and proteins by metal ions and complexes. Curr. Org. Chem. 2006, 10, 1035-1049.

3. Delahunty, C.; Yates, J.R. Protein identification using 2D-LC-MS/MS. Methods 2005, 35, 248-255.

4. Meyer, B.; Papasotiriou, D.G.; Karas, M. 100\% protein sequence coverage: A modern form of surrealism in proteomics. Amino Acids 2011, 41, 291-310.

5. Swaney, D.L.; Wenger, C.D.; Coon, J.J. Value of using multiple proteases for large-scale mass spectrometry-based proteomics. J. Proteome Res. 2010, 9, 1323-1329.

6. Bolumar, T.; Bindrich, U.; Toepfl, S.; Toldra, F.; Heinz, V. Effect of electrohydraulic shockwave treatment on tenderness, muscle cathepsin and peptidase activities and microstructure of beef loin steaks from holstein young bulls. Meat Sci. 2014, 98, 759-765.

7. Rai, S.K.; Mukherjee, A.K. Optimization of production of an oxidant and detergent-stable alkaline beta-keratinase from brevibacillus sp strain AS-S10-II: Application of enzyme in laundry detergent formulations and in leather industry. Biochem. Eng. J. 2011, 54, 47-56.

8. Polaina, J.; MacCabe, A.P. Industrial Enzymes: Structure, Function and Applications; Springer: Dordrecht, The Netherlands, 2007.

9. Katz, M.L.; Coates, J.R.; Sibigtroth, C.M.; Taylor, J.D.; Carpentier, M.; Young, W.M.; Wininger, F.A.; Kennedy, D.; Vuillemenot, B.R.; O’Neill, C.A.; et al. Enzyme replacement therapy attenuates disease progression in a canine model of late-infantile neuronal ceroid lipofuscinosis (CLN2 disease). J. Neurosci. Res. 2014, 92, 1591-1598.

10. Pope, M.T. Heteropoly and Isopoly Oxometalates; Springer-Verlag: New York, NY, USA, 1983.

11. Bassil, B.S.; Kortz, U. Recent advances in lanthanide-containing polyoxotungstates. Z. Anorg. Allg. Chem. 2010, 636, 2222-2231. 
12. Cronin, L.; Mueller, A. From serendipity to design of polyoxometalates at the nanoscale, aesthetic beauty and applications. Chem. Soc. Rev. 2012, 41, 7333-7334.

13. Long, D.-L.; Tsunashima, R.; Cronin, L. Polyoxometalates: Building blocks for functional nanoscale systems. Angew. Chem. Int. Ed. 2010, 49, 1736-1758.

14. Proust, A.; Thouvenot, R.; Gouzerh, P. Functionalization of polyoxometalates: Towards advanced applications in catalysis and materials science. Chem. Commun. 2008, 1837-1852.

15. Lv, H.; Geletii, Y.V.; Zhao, C.; Vickers, J.W.; Zhu, G.; Luo, Z.; Song, J.; Lian, T.; Musaev, D.G.; Hill, C.L.; et al. Polyoxometalate water oxidation catalysts and the production of green fuel. Chem. Soc. Rev. 2012, 41, 7572-7589.

16. Zakzeski, J.; Bruijnincx, P.C.A.; Jongerius, A.L.; Weckhuysen, B.M. The catalytic valorization of lignin for the production of renewable chemicals. Chem. Rev. 2010, 110, 3552-3599.

17. Chen, J.; Wang, S.; Huang, J.; Chen, L.; Ma, L.; Huang, X. Conversion of cellulose and cellobiose into sorbitol catalyzed by ruthenium supported on a polyoxometalate/metal-organic framework hybrid. Chemsuschem 2013, 6, 1545-1555.

18. Mueller, A.; Garai, S.; Schaeffer, C.; Merca, A.; Boegge, H.; Al-Karawi, A.J.M.; Prasad, T.K. Water repellency in hydrophobic nanocapsules-molecular view on dewetting. Chem. Eur. J. 2014, 20, 6659-6664.

19. Kourasi, M.; Wills, R.G.A.; Shah, A.A.; Walsh, F.C. Heteropolyacids for fuel cell applications. Electrochim. Acta 2014, 127, 454-466.

20. Zhang, W.-B.; Yu, X.; Wang, C.-L.; Sun, H.-J.; Hsieh, I.F.; Li, Y.; Dong, X.-H.; Yue, K.; Van Horn, R.; Cheng, S.Z.D.; et al. Molecular nanoparticles are unique elements for macromolecular science: From "nanoatoms" to giant molecules. Macromolecules 2014, 47, 1221-1239.

21. Yvon, C.; Surman, A.J.; Hutin, M.; Alex, J.; Smith, B.O.; Long, D.-L.; Cronin, L. Polyoxometalate clusters integrated into peptide chains and as inorganic amino acids: Solution-and solid-phase approaches. Angew. Chem. Int. Ed. 2014, 53, 3336-3341.

22. McGregor, D.; Burton-Pye, B.P.; Lukens, W.W.; Howell, R.C.; Francesconi, L.C. Insights into stabilization of the ${ }^{99} \mathrm{Tc}^{\mathrm{V}} \mathrm{O}$ core for synthesis of ${ }^{99} \mathrm{Tc}^{\mathrm{V}} \mathrm{O}$ compounds. Eur. J. Inorg. Chem. 2014, 2014, 1082-1089.

23. Aureliano, M.; Fraqueza, G.; Ohlin, C.A. Ion pumps as biological targets for decavanadate. Dalton Trans. 2013, 42, 11770-11777.

24. Iqbal, J.; Barsukova-Stuckart, M.; Ibrahim, M.; Ali, S.U.; Khan, A.A.; Kortz, U. Polyoxometalates as potent inhibitors for acetyl and butyrylcholinesterases and as potential drugs for the treatment of alzheimer's disease. Med. Chem. Res. 2013, 22, 1224-1228.

25. Briand, L.E.; Baronetti, G.T.; Thomas, H.J. The state of the art on wells-dawson heteropoly-compounds-A review of their properties and applications. Appl. Catal. A 2003, 256, $37-50$.

26. Song, F.; Ding, Y.; Zhao, C. Progress in polyoxometalates-catalyzed water oxidation. Acta Chim. Sin. 2014, 72, 133-144.

27. Mizuno, N.; Nozaki, C.; Kiyoto, I.; Misono, M. Highly efficient utilization of hydrogen peroxide for selective oxygenation of alkanes catalyzed by diiron-substituted polyoxometalate precursor. J. Am. Chem. Soc. 1998, 120, 9267-9272. 
28. Mizuno, N.; Nozaki, C.; Kiyoto, I.; Misono, M. Selective oxidation of alkenes catalyzed by di-iron-substituted silicotungstate with highly efficient utilization of hydrogen peroxide. J. Catal. 1999, 182, 285-288.

29. Orlandi, M.; Argazzi, R.; Sartorel, A.; Carraro, M.; Scorrano, G.; Bonchio, M.; Scandola, F. Ruthenium polyoxometalate water splitting catalyst: Very fast hole scavenging from photogenerated oxidants. Chem. Commun. 2010, 46, 3152-3154.

30. Stephan, H.; Kubeil, M.; Emmerling, F.; Mueller, C.E. Polyoxometalates as versatile enzyme inhibitors. Eur. J. Inorg. Chem. 2013, 1585-1594.

31. Chen, Q.; Yang, L.; Zheng, C.; Zheng, W.; Zhang, J.; Zhou, Y.; Liu, J. Mo polyoxometalate nanoclusters capable of inhibiting the aggregation of a beta-peptide associated with alzheimer's disease. Nanoscale 2014, 6, 6886-6897.

32. Bashan, A.; Yonath, A. The linkage between ribosomal crystallography, metal ions, heteropolytungstates and functional flexibility. J. Mol. Struct. 2008, 890, 289-294.

33. Hungerford, G.; Hussain, F.; Patzke, G.R.; Green, M. The photophysics of europium and terbium polyoxometalates and their interaction with serum albumin: A time-resolved luminescence study. Phys. Chem. Chem. Phys. 2010, 12, 7266-7275.

34. Stroobants, K.; Moelants, E.; Ly, H.G.T.; Proost, P.; Bartik, K.; Parac-Vogt, T.N. Polyoxometalates as a novel class of artificial proteases: Selective hydrolysis of lysozyme under physiological ph and temperature promoted by a cerium(IV) keggin-type polyoxometalate. Chem. Eur. J. 2013, 19, 2848-2858.

35. Weinstein, S.; Jahn, W.; Glotz, C.; Schlunzen, F.; Levin, I.; Janell, D.; Harms, J.; Kolln, I.; Hansen, H.A.S.; Gluhmann, M.; et al. Metal compounds as tools for the construction and the interpretation of medium-resolution maps of ribosomal particles. J. Struct. Biol. 1999, 127, 141-151.

36. Zhang, G.; Keita, B.; Brochon, J.-C.; de Oliveira, P.; Nadjo, L.; Craescu, C.T.; Miron, S. Molecular interaction and energy transfer between human serum albumin and polyoxometalates. J. Phys. Chem. B 2007, 111, 1809-1814.

37. Zhang, G.; Keita, B.; Craescu, C.T.; Miron, S.; de Oliveira, P.; Nadjo, L. Molecular interactions between wells-dawson type polyoxometalates and human serum albumin. Biomacromolecules $\mathbf{2 0 0 8}$, 9, 812-817.

38. Zheng, L.; Ma, Y.; Zhang, G.; Yao, J.; Bassil, B.S.; Kortz, U.; Keita, B.; de Oliveira, P.; Nadjo, L.; Craescu, C.T.; et al. Molecular interaction between a gadolinium-polyoxometalate and human serum albumin. Eur. J. Inorg. Chem. 2009, 5189-5193.

39. Zheng, L.; Ma, Y.; Zhang, G.; Yao, J.; Keita, B.; Nadjo, L. A multitechnique study of europium decatungstate and human serum albumin molecular interaction. Phys. Chem. Chem. Phys. 2010, 12, 1299-1304.

40. Absillis, G.; Cartuyvels, E.; van Deun, R.; Parac-Vogt, T.N. Hydrolytic cleavage of an rna-model phosphodiester catalyzed by a highly negatively charged polyoxomolybdate $\mathrm{Mo}_{7} \mathrm{O}_{24}{ }^{6-}$ cluster. J. Am. Chem. Soc. 2008, 130, 17400-17408.

41. Cartuyvels, E.; Absillis, G.; Parac-Vogt, T.N. Questioning the paradigm of metal complex promoted phosphodiester hydrolysis: $\mathrm{Mo}_{7} \mathrm{O}_{24}{ }^{6-}$ polyoxometalate cluster as an unlikely catalyst for the hydrolysis of a DNA model substrate. Chem. Commun. 2008, 85-87. 
42. Cartuyvels, E.; van Hecke, K.; van Meervelt, L.; Gorller-Walrand, C.; Parac-Vogt, T.N. Structural characterization and reactivity of gamma-octamolybdate functionalized by proline. J. Inorg. Biochem. 2008, 102, 1589-1598.

43. Van Lokeren, L.; Cartuyvels, E.; Absillis, G.; Willem, R.; Parac-Vogt, T.N. Phosphoesterase activity of polyoxomolybdates: Diffusion ordered NMR spectroscopy as a tool for obtaining insights into the reactivity of polyoxometalate clusters. Chem. Commun. 2008, 2774-2776.

44. Steens, N.; Ramadan, A.M.; Absillis, G.; Parac-Vogt, T.N. Hydrolytic cleavage of DNA-model substrates promoted by polyoxovanadates. Dalton Trans. 2010, 39, 585-592.

45. Steens, N.; Ramadan, A.M.; Parac-Vogt, T.N. When structural and electronic analogy leads to reactivity: The unprecedented phosphodiesterase activity of vanadates. Chem. Commun. 2009, 965-967.

46. Vanhaecht, S.; Absillis, G.; Parac-Vogt, T.N. Hydrolysis of DNA model substrates catalyzed by metal-substituted wells-dawson polyoxometalates. Dalton Trans. 2012, 41, 10028-10034.

47. Ho, P.H.; Mihaylov, T.; Pierloot, K.; Parac-Vogt, T.N. Hydrolytic activity of vanadate toward serine-containing peptides studied by kinetic experiments and dft theory. Inorg. Chem. 2012, 51, 8848-8859.

48. Ho, P.H.; Stroobants, K.; Parac-Vogt, T.N. Hydrolysis of serine-containing peptides at neutral ph promoted by $\mathrm{MoO}_{4}{ }^{2-}$ oxyanion. Inorg. Chem. 2011, 50, 12025-12033.

49. Hong Giang, T.L.; Absillis, G.; Bajpe, S.R.; Martens, J.A.; Parac-Vogt, T.N. Hydrolysis of dipeptides catalyzed by a zirconium(IV)-substituted lindqvist type polyoxometalate. Eur. J. Inorg. Chem. 2013, 4601-4611.

50. Hong Giang, T.L.; Absillis, G.; Parac-Vogt, T.N. Amide bond hydrolysis in peptides and cyclic peptides catalyzed by a dimeric $\mathrm{Zr}(\mathrm{IV})$-substituted keggin type polyoxometalate. Dalton Trans. 2013, 42, 10929-10938.

51. Absillis, G.; Parac-Vogt, T.N. Peptide bond hydrolysis catalyzed by the wells-dawson $\mathrm{Zr}\left(\alpha_{2}-\mathrm{P}_{2} \mathrm{~W}_{17} \mathrm{O}_{61}\right)_{2}$ polyoxometalate. Inorg. Chem. 2012, 51, 9902-9910.

52. Stroobants, K.; Absillis, G.; Moelants, E.; Proost, P.; Parac-Vogt, T.N. Regioselective hydrolysis of human serum albumin by $\mathrm{Zr}^{\mathrm{IV}}$-substituted polyoxotungstates at the interface of positively charged protein surface patches and negatively charged amino acid residues. Chem. Eur. J. 2014, 20, 3894-3897.

53. Stroobants, K.; Goovaerts, V.; Absillis, G.; Bruylants, G.; Moelants, E.; Proost, P.; Parac-Vogt, T.N. Molecular origin of the hydrolytic activity and fixed regioselectivity of a zriv-substituted polyoxotungstate as artificial protease. Chem. Eur. J. 2014, 20, 9567-9577.

54. Vanhaecht, S.; Absillis, G.; Parac-Vogt, T.N. Amino acid side chain induced selectivity in the hydrolysis of peptides catalyzed by a $\mathrm{Zr}(\mathrm{IV})$-substituted wells-dawson type polyoxometalate. Dalton Trans. 2013, 42, 15437-15446.

55. Ajloo, D.; Behnam, H.; Saboury, A.A.; Mohamadi-Zonoz, F.; Ranjbar, B.; Moosavi-Movahedi, A.A.; Hasani, Z.; Alizadeh, K.; Gharanfoli, M.; Amani, M.; et al. Thermodynamic and structural studies on the human serum albumin in the presence of a polyoxometalate. Bull. Korean Chem. Soc. 2007, $28,730-736$. 
56. Xiao, J.B.; Chen, X.Q.; Jiang, X.Y.; Hilczer, M.; Tachiya, M. Probing the interaction of trans-resveratrol with bovine serum albumin: A fluorescence quenching study with tachiya model. J. Fluoresc. 2008, 18, 671-678.

57. Lakowicz, J.R. Principles of Fluorescence Spectroscopy; Springer: New York, NY, USA, 2006.

58. Goovaerts, V.; Stroobants, K.; Absillis, G.; Parac-Vogt, T.N. Molecular interactions between serum albumin proteins and keggin type polyoxometalates studied using luminescence spectroscopy. Phys. Chem. Chem. Phys. 2013, 15, 18378-18387.

59. Sugio, S.; Kashima, A.; Mochizuki, S.; Noda, M.; Kobayashi, K. Crystal structure of human serum albumin at 2.5 angstrom resolution. Protein Eng. 1999, 12, 439-446.

60. Stroobants, K.; Saadallah, D.; Bruylants, G.; Parac-Vogt, T.N. Thermodynamic study of the interaction between hen egg white lysozyme and Ce(IV)-keggin polyoxotungstate as artificial protease. Phys. Chem. Chem. Phys. 2014, 16, 21778-21787.

61. Zhang, G.; Keita, B.; Craescu, C.T.; Miron, S.; de Oliveira, P.; Nadjo, L. Polyoxometalate binding to human serum albumin: A thermodynamic and spectroscopic approach. J. Phys. Chem. B 2007, $111,11253-11259$.

62. Kato, C.N.; Shinohara, A.; Hayashi, K.; Nomiya, K. Syntheses and X-ray crystal structures of zirconium(IV) and hafnium(IV) complexes containing monovacant wells-dawson and keggin polyoxotungstates. Inorg. Chem. 2006, 45, 8108-8119.

63. Lv, H.J.; Song, J.; Geletii, Y.V.; Vickers, J.W.; Sumliner, J.M.; Musaev, D.G.; Kogerler, P.; Zhuk, P.F.; Bacsa, J.; Zhu, G.B.; et al. An exceptionally fast homogeneous carbon-free cobalt-based water oxidation catalyst. J. Am. Chem. Soc. 2014, 136, 9268-9271.

64. Song, F.Y.; Ding, Y.; Ma, B.C.; Wang, C.M.; Wang, Q.; Du, X.Q.; Fua, S.; Song, J. $\mathrm{K}_{7}\left[\mathrm{Co}^{\mathrm{III}} \mathrm{Co}^{\mathrm{II}}\left(\mathrm{H}_{2} \mathrm{O}\right) \mathrm{W}_{11} \mathrm{O}_{39}\right]$ : A molecular mixed-valence keggin polyoxometalate catalyst of high stability and efficiency for visible light-driven water oxidation. Energy Environ. Sci. 2013, 6, 1170-1184.

65. Song, J.; Luo, Z.; Britt, D.K.; Furukawa, H.; Yaghi, O.M.; Hardcastle, K.I.; Hill, C.L. A multiunit catalyst with synergistic stability and reactivity: A polyoxometalate-metal organic framework for aerobic decontamination. J. Am. Chem. Soc. 2011, 133, 16839-16846.

66. Zerbe, O. Bionmr in Drug Research; Wiley-VCH: Weinheim, Germany, 2003; Volume 16.

67. Kholdeeva, O.A.; Maksimov, G.M.; Maksimovskaya, R.I.; Vanina, M.P.; Trubitsina, T.A.; Naumov, D.Y.; Kolesov, B.A.; Antonova, N.S.; Carbo, J.J.; Poblet, J.M.; et al. $\mathrm{Zr}(\mathrm{IV})$-monosubstituted keggin-type dimeric polyoxometalates: Synthesis, characterization, catalysis of $\mathrm{H}_{2} \mathrm{O}_{2}$-based oxidations, and theoretical study. Inorg. Chem. 2006, 45, 7224-7234.

68. Kholdeeva, O.A.; Maksimovskaya, R.I. Titanium- and zirconium-monosubstituted polyoxometalates as molecular models for studying mechanisms of oxidation catalysis. J. Mol. Catal. A 2007, 262, 7-24.

69. Nomiya, K.; Saku, Y.; Yamada, S.; Takahashi, W.; Sekiya, H.; Shinohara, A.; Ishimaru, M.; Sakai, Y. Synthesis and structure of dinuclear hafnium(IV) and zirconium(IV) complexes sandwiched between 2 mono-lacunary alpha-keggin polyoxometalates. Dalton Trans. 2009, 5504-5511; doi:10.1039/b902296a. 
70. Carabineiro, H.; Villanneau, R.; Carrier, X.; Herson, P.; Lemos, F.; Ribeiro, F.R.; Proust, A.; Che, M. Zirconium-substituted isopolytungstates: Structural models for zirconia-supported tungsten catalysts. Inorg. Chem. 2006, 45, 1915-1923.

71. Gaunt, A.J.; May, I.; Collison, D.; Holman, K.T.; Pope, M.T. Polyoxometal cations within polyoxometalate anions. Seven-coordinate uranium and zirconium heteroatom groups in $\left[\left(\mathrm{UO}_{2}\right)_{12}\left(\mu_{3}-\mathrm{O}\right)_{4}\left(\mu_{2}-\mathrm{H}_{2} \mathrm{O}\right)_{12}\left(\mathrm{P}_{2} \mathrm{~W}_{15} \mathrm{O}_{56}\right)_{4}\right]^{32-}$ and $\left[\mathrm{Zr}_{4}\left(\mu_{3}-\mathrm{O}\right)_{2}\left(\mu_{2}-\mathrm{OH}\right)_{2}\left(\mathrm{H}_{2} \mathrm{O}\right)_{4}\left(\mathrm{P}_{2} \mathrm{~W}_{16} \mathrm{O}_{59}\right)_{2}\right]^{14-}$. J. Mol. Struct. 2003, 656, 101-106.

(C) 2015 by the authors; licensee MDPI, Basel, Switzerland. This article is an open access article distributed under the terms and conditions of the Creative Commons Attribution license (http://creativecommons.org/licenses/by/4.0/). 